\title{
Smart Military Electrical Grids
}

\section{Zsolt VÉGVÁRI ${ }^{1}$}

Today's society is increasingly dependent on electricity and the armed forces also face this problem. In this regards the issue of providing electricity in field conditions when power lines are not available is extremely interesting. The technology of the generators used in the fields has developed only at a minimal level over the past half century while the demand for electricity has multiplied. Logistics becomes more and more difficult and fuel caravans are one of the most vulnerable parts of military actions. Smart grid technologies based on RES are no longer a novelty for civil engineering. How are these used in military environments and what are the limits of their application? These are the questions I would like to find some answers to.

Keywords: smart grids, hybrid power supply, field power supply

\section{Global Challenges of Energy}

Energy is an indispensable element of our modern civilization. In prehistoric times people were a part of the nature and they used their environment like any other organism, but about 5,000 years ago mankind began to change the environment in order to survive. The creation and the maintenance of the artificial environment needed a lot of energy but the available energy — manpower and animal power — was limited for centuries. By and by mankind discovered how to use the power of water and wind but the real breakthrough was the spread of fossil energies. Now the total energy consumption of the World is more than 13 billion tonnes oil equivalent (TOE) ${ }^{3}$ [1: 8] and the $85 \%$ of this amount comes from fossil sources. ${ }^{4}$ Nowadays sustainable development is a keyword in modern science and the yield, the transportation and storage of the necessary energy is a really big challenge for us. Unfortunately, by using this extremely huge amount of energy, human activities changed the climate of the whole planet so only bringing up the energy is no longer enough, we have to find better and cleaner ways than ever before.

Since of its development electrical energy is getting a bigger part of the energy consumption of the World. In 2017 it was 24,816.4 TWh. [1: 46] In SI units this 89,339 million GJ means that one third of the primary energies turned into electricity ${ }^{5}$ before the final use.

1 Lieutenant Colonel, Senior Executive Officer in the Defence Technology Research Centre of the Hungarian Ministry of Defence; National University of Public Service, Doctoral School of Military Engineering; e-mail: vegvari.zsolt@hm.gov.hu

2 Renewable Energy Sources.

3 One-litre of crude oil contains about $38.5 \mathrm{MJ}$ energy in SI units. One-litre crude oil is $0.85-0.95 \mathrm{~kg}$ so one ton contains about 41.8 GJ. 13,276.3 million TOE = 555,852.1 million GJ.

4 Crude oil, natural gas and coal.

5 The efficiencies of the methods of producing electrical energy are very different. A PV panel has only 20-25\%, but the best power plans have about $50 \%$. In this calculation I counted half of the total used primary energy changed into electricity. 
Now it's the most important secondary energy ${ }^{6}$ because of its flexibility and easy usability. Electricity can be produced from any other kind of energy. Usually we use generators powered by heat energy of fossils, nuclear reaction, water or wind but there are methods for direct transformation too. Semiconductor devices can generate electrical energy directly for example from temperature difference (Peltier-cells) or solar radiation (solar cells or PV cells ${ }^{7}$ ). Of course, it is similarly simple to transform the electricity into any needed types of end use energy. The high voltage electric power line is the most economical way of energy transport because its loss is less than $1 \%$ every 100 kilometres. [2] The greatest challenge of electricity of our days is storage. Batteries are very easy to handle but their energy density ${ }^{8}$ is substantially less than fossil fuels.

\section{Electrical Energy Issues in the Security Domain}

Energy is also very important for the defence sector. In ancient times warfare was absolutely based on manpower and horsepower, but after the industrial revolution it changed totally. In WWII a daily operation of a single soldier took 4 litres of oil equivalent energy. In the Vietnam War it was more than 33 litres of oil equivalent and during the Iraqi mission a single allied soldier needed 81 litres of oil equivalent of energy a day. [3: 2] Based on these data we can conclude that defence is an extremely energy-intensive field of the human activities and the energy necessity of the military actions expectedly will grow in the near future.

Until the beginning of the $20^{\text {th }}$ century armies didn't use electricity at all. The first electrical military devices-the telephones were released during WW1 but their petty consumption was able to be supplied by batteries. Between the world wars radio equipment became the most important communication device but the energy demand of the contemporary vacuum tube amplifiers and other circuits was extremely high compared to the telephones. Because of the low energy density of the batteries the needed electricity was no more "portable", it had to be generated "in situ". Interestingly enough, not so many other electric devices were used by armies. Petroleum was commonly used for camp lighting and the primary source of heating was simple firewood.

After WW2 camp lighting fully changed into electrical systems; then air conditioners, computers and other electrical devices also appeared. Now no modern armies can exist without electrical energy and this is especially true for the deployed units, as temporary military camps are totally based on electricity. As we can see, electricity is an essential part of temporary military accommodation if the military operations are taking place where there is no infrastructure or it is damaged, so the very comfortable and cheap wired power supply is unavailable. Producing the necessary energy under these harsh conditions is already a really serious challenge. However, the expected demands will increase even on the basis of currently existing technologies and we must be aware that most of the future technologies are also significant electrical consumers. The development potential of

6 Primary energy means energy sources that can be found in nature like fossils or renewable energies. Secondary energies are carriers of energy transformed from primaries by human engineering.

7 In the photovoltaic devices the incoming photons between semiconductor layers induce electron flow without any concomitants like motion, noise or heat.

8 Energy density is the amount of energy stored in a given space or weight for example $\mathrm{J} / \mathrm{m}^{3}$ or $\mathrm{kWh} / \mathrm{kg}$. 
traditional armament technologies are getting narrower and the future weapons will need an extremely huge amount of energy_in most cases in electrical form. [4: 7]

\section{The Evolution of Electricity Production in Field Conditions}

As it was mentioned, the first military electrical devices were supplied by batteries, but further on by using radios, the electricity demand exceeded the possibilities of battery technology, so application of electric rotating machines was needed for electrical power generation. The first electric rotating machines were based on human muscle strength and were called "pedal-generators". As radios needed DC, these types of equipment applied dynamos. ${ }^{9}$ This solution was very simple, reliable and there was no need for fuel supply but its performance was limited to the human body. That is why lots of countries developed their own generators powered by gasoline engine in the 1930s of the last century. These developments were independent but similar demands resulted in very similar devices. [5: 571]

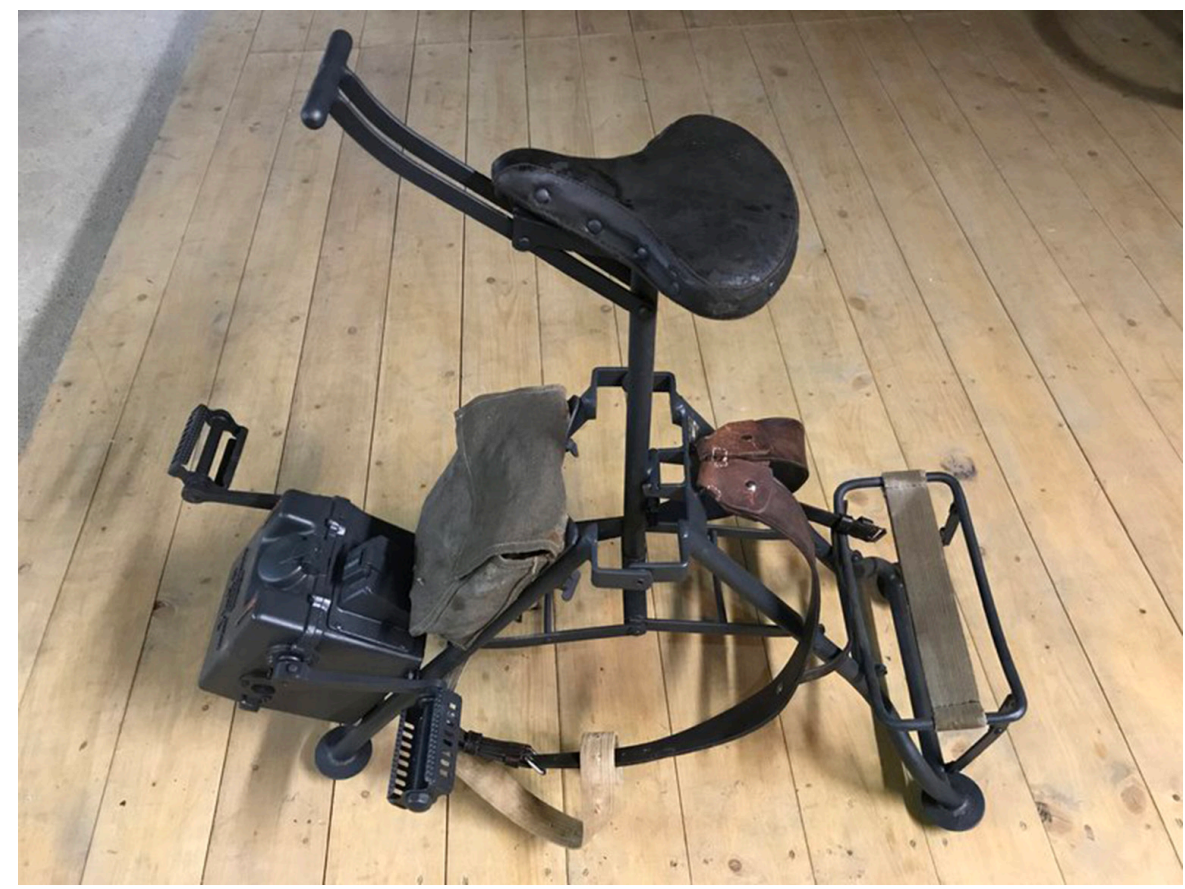

Figure 1. German TP5 pedal-generator before WW2. [17]

At the same time almost exclusively, radio equipment needed field electricity independently from those vehicles that had an on-board electric grid. It means that the majority of field generators were a part of a radio station. Most of the armies were not fully mechanized, for example the Hungarian forces also used horse drawn wagons to transport their radios so

9 Dynamo is a type of electric rotating machine providing direct current (DC). 
the weight of the generators was very important. These generators used gasoline. The diesel engines had better efficiency but their construction was more complicated and that was not an advantage in field conditions. As most of the vehicles also consumed gasoline there was no need to create a new fuels supply chain. Lying cylinder arrangement were often used in order to reduce the resonance. The air cooled, two-stroke boxer engines were very undemanding and easy to maintain. [5: 572]

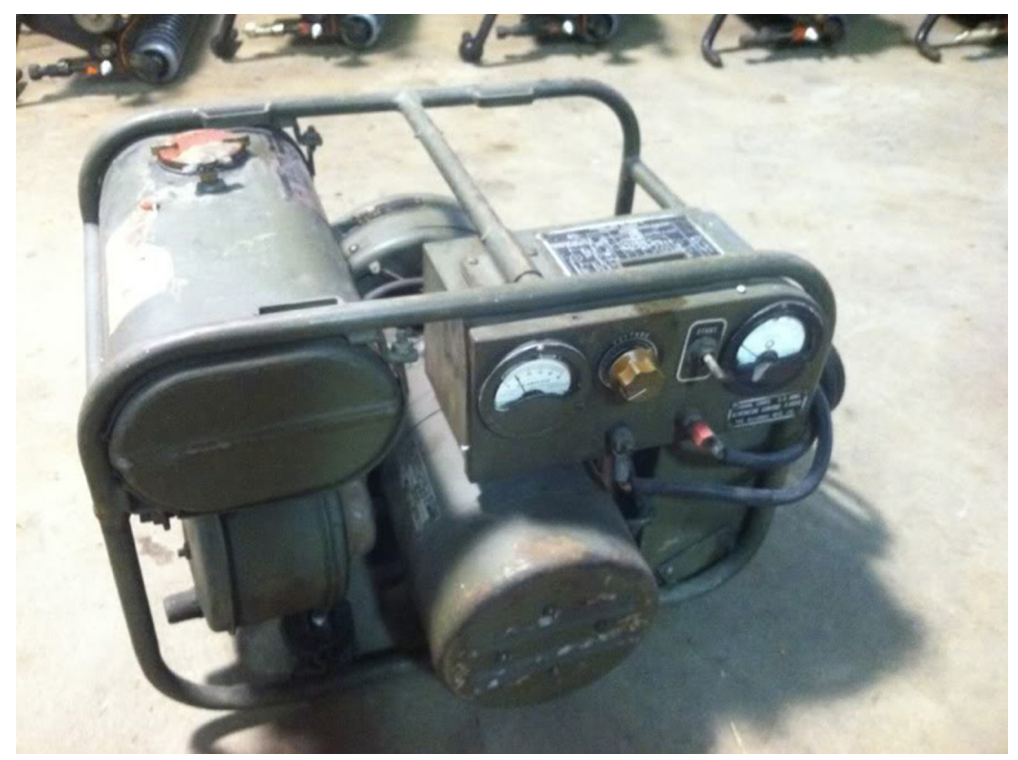

Figure 2. A typical small gasoline generator US GE-12-G from WW2.

It has a $0.5 \mathrm{~kW}$ air-cooled 2-stroke 2-cylinder engine and produces 12 volts DC. [5: 572]

The applied electrical rotating machine was usually a dynamo, even though it was already well known that alternators ${ }^{10}$ were more efficient and their performance was less dependent on the rotating speed of the engine. Alternators produce alternate current, but radios needed direct current, and the contemporary rectifiers were big, heavy and also made significant power loss. [6] As $80-90 \%$ of the power consumption of radios was made by heating the vacuum tubes, the actual power supply didn't depend on the working mode. This almost constant power demand was favourable for dynamos. The engine, the fuel tank, the dynamo and the attached connectors, etc. were installed on a simple welded steel frame without any cover in order to reduce the weight.

After WW2 diesel engines were widespread in land vehicles and their usage in field generators became more favourable owing to their better efficiency. Later on, more and more parts of the equipment of the camp accommodation became electrified and most part of the used electrical devices was the same as the ones used in the barracks. As the deployed units increasingly needed the same electrical power as in their peace-time quarters, the same electrical networks were installed in the temporary camps, too. The critical

10 An alternator is a type of electric rotating machine providing alternate current (AC). 
info-communication elements still kept their individual small generators but all other consumers were linked into a grid supplied with one really big generator. Nowadays these generators are one of the most important pillars of the field logistic supply system. Their power contains hundreds of $\mathrm{kW}$-s and can supply even a full battalion. Normally these sets are towed or self-propelled ones, and rarely mounted in a standard commercial container.

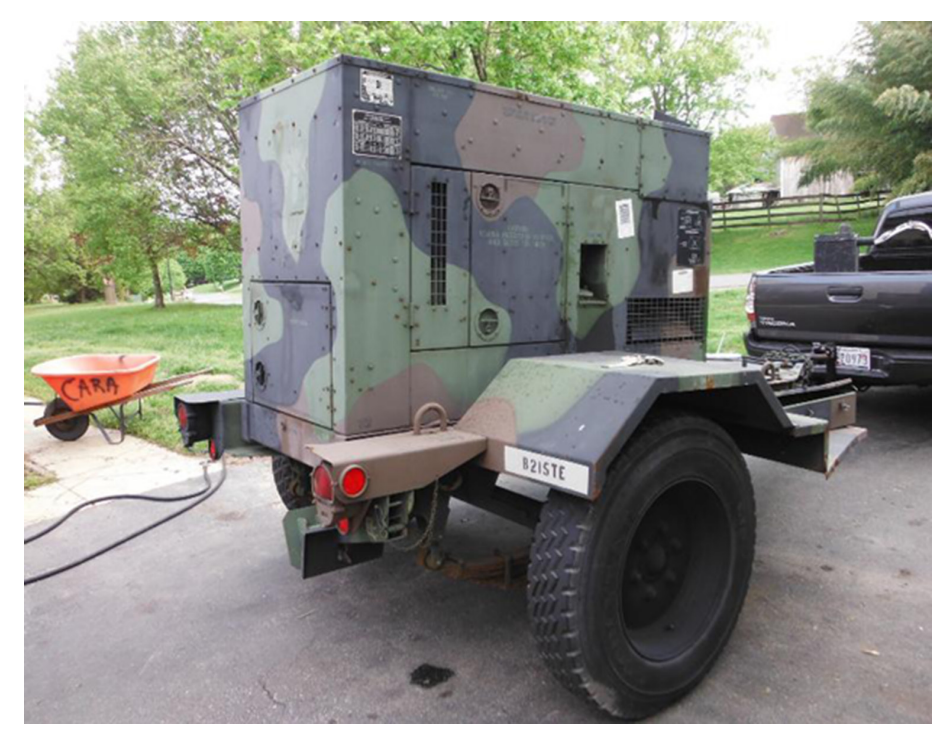

Figure 3. US MEP-805A 3 tons towed military generator driven by a John Deere 4 strokes diesel engine. Max output is $30 \mathrm{~kW}$ AC. It has EMP proof capability and quiet working method for tactical missions. [18]

During real military missions the primary goal is always completing the mission, the secondary goal is reducing the casualties and only then can saving money or the environment be considered. So, if we need more electrical power in the future for our deployed military units it might seem a simple logistic question. Theoretically we can use more generators and we can consume more fuel but in fact it's a little bit more difficult. It is well known that the most vulnerable parts of the military missions are the supply lines. More supply caravans mean more expensive logistic background and the casualties also will spectacularly rise. If we want to reduce the dependency on fuel supply of our deployed forces, we could improve the efficiency of electrical power generation or we can gain electricity from other sources in the field.

Unfortunately, there are no real possibilities to improve sensibly the efficiency of generators. The efficiency of the alternators can reach 95\%, so these machines belong to the best ones that were ever made by humans. [7: 187] Diesel engines have much worse efficiency, only about $40 \%$. It is slightly better than gasoline engines, but there are still technical barriers for further efficiency increasing. The development trends of diesel engines-for example turbo charging — create complicated structures but their increase of efficiency is only 1-2\% and the complex machines are more expensive, need more maintenance and more often fail. Practically the heat loss of any kinds of heat machines can't be decreased below 50-60\%. 
Theoretically there are several ways of using the remaining heat by Peltier-cells, steam engines or Stirling-engines but these types of equipment are also expensive, complicated and make only a minimal improvement.

A camp-size nuclear plant would be technically appropriate for the advanced states but for now it seems to be too risky for their own troops. There are several projects for using hydrogen or methanol fuel-cells in the field but the technology is still in its elementary stage. Scientists are looking for more persistent electrodes and cheaper catalysts than platinum. If this technology was much more mature then it even would need a separate fuel supply chain, and this would be a logistic nightmare. Probably the only real alternatives of fossils for deployed units are the renewable energy sources at this moment. Using of RES becomes less and less particular in the civil economy, but their integration into an independent military grid means a very different challenge.

\section{RES in Military Fields}

Renewables are natural resources that can replenish themselves naturally over time. Practically these resources can be gained but their left quantity won't be less. Basically, five main types of RES are available in the biosphere of Earth. Biomass (including all wasted or cultivated organic materials), solar radiation, wind power, geothermic energy and hydro power. Some researchers separate tidal and ocean waves but in this article, it makes no sense for this separation.

There are dozens of projects all over the World with the target to integrate biomass into the fuel supply chain. In most cases biomass can reduce the dependency on fossils and has favourable effects on the economy and the environment. By this criteria biomass could be very useful for armies during their peace-time activities but unfortunately, it's not a proper choice for the deployed forces. Namely, it's not worth establishing a new logistic supply system because the energy density ${ }^{11}$ of biofuels is less than the refined petroleum derivate. [8]

11 Energy density is the amount of stored energy in a given space or weight. The SI unit is the $\mathrm{J} / \mathrm{m} 3 \mathrm{but}$ sometimes it's better to use a weight-related one. For example, hydrogen gas has very good energy density related to its weight and much worse related to its volume. 


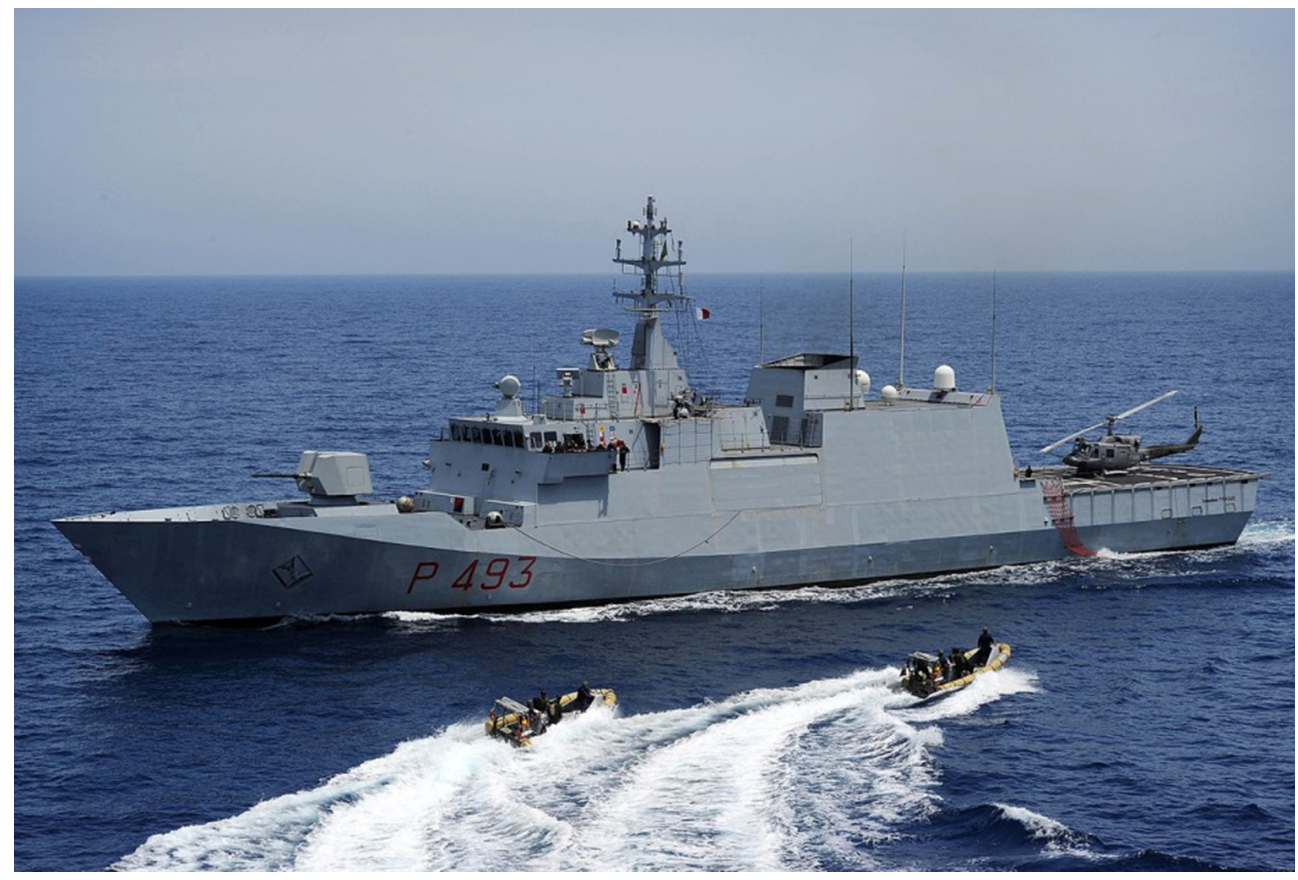

Figure 4. The 1520 tons ITS Commandante Foscari patrol vessel is a part of the Italian Green Fleet Program propelled by "Green Diesel" acquired from vegetable oils and tallow. This fuel conforms to F76 NATO navy fuel standard. [19]

Hydro power is a very clean and economic source of electricity but it has two attributes which essentially excludes it from military operations. [9: 304] Gaining the energy of water needs enormously big and heavy infrastructure that is not mobile at all. In most cases of the possible military operations there is not enough water even for drinking. Using the heat of the Earth in the battlefield is similarly problematic because the equipment of geothermal harvesting is heavy and not easy to deploy and dismantle. [10: 19] In some parts of the Earth the geothermal gradient ${ }^{12}$ is low or the lithosphere is too massive to enable the drill.

Solar and wind power seem to be the right choice for deployed military troops. These are well scalable, mobile enough and do not need too many infrastructural parts. These are available almost in all regions of the Earth but of course their intensity is very changeable. Unfortunately, whereas the gained energy from bio, hydro and geothermal sources are accurately predictable, wind and solar intensity are really unreliable. [11: 46-50] It means that wind and solar energy can’t be used individually but we can take their advantages mixed with conventional generators in the same grid.

12 Geothermal gradient is the rate of the increasing temperature towards the interior of Earth. The average rate is $3 \mathrm{C}^{\circ}$ per 100 meters but in Iceland it could be even ten times better. 
Table 1. The important features of RES in terms of military applicability.

[The author's compilation.]

\begin{tabular}{|l|l|l|l|l|l|}
\hline Renewable & Biomass & Hydro & Geothermal & Wind & Solar \\
\hline scalability & n/a & bad & medium & good & very good \\
\hline reliability & good & good & very good & medium & bad \\
\hline mobility & n/a & none & very bad & medium & good \\
\hline
\end{tabular}

\section{Classifying Micro Grids and their Components}

Military grids are based on civil micro grid technologies so it's inevitable to examine their structure. An electrical grid can be very simple. If we have a power source (a plant in the power grids), a consumer and they are connected with a power cable, that's a grid. On a smaller scale if the power source is a generator we're talking about micro grids. Of course, depending on the number of sources and consumers, junctions can be created and the topography of the whole system would be very complicated but that's still a simple grid. The electrical grids of deployed units are always micro grids, because battalions or bigger units never settle down close to each other and it is not an expedient to connect them into a bigger energy network.

If a grid contains conventional plant(s) or generator(s) and some RES too, that's a hybrid grid. In the civil electrical power infrastructure micro grids are invested for economic reasons and they're connected into a big power grid. If a micro grid works independently without any power line connection, that's a so called off-grid or an “island.” [12: 31] Usually the temporary military electrical networks are off-grids, even if those have got the capability to connect power lines, their typical working method is "island."

The last and the least clear type we have to know is the smart grid. In a smart grid there is a central control unit which has the information about both demand and supply and by these data it has the capability to change the direction and the amount of energy flow. Big power grids are always "smart" but of course there is the possibility of manual control. If conventional generators and RES are mixed into a hybrid system, there is the theoretical possibility of the manual management but it's not really lifelike during a military action. In the military applications hybrid grids are always "smart" ones.

It is very important, that if an island solution uses some RES, the system has to contain a storage unit in order to supply electricity when RES is not working until the generator starts. It's usually a battery group or it can be a hydrogen fuel cell with a water separator ${ }^{13}$ or both. Other solutions like mechanical (gravity) storages are still in their technological beginning and their size doesn't allow using them in some parts of temporary military facilities. In most cases the power sources are not directly connected with the consumers but via the storages. It makes continuous load for batteries and current transformers make losses but on the other hand this structure ensures the constant quality of power supply.

13 When there is a surplus of solar energy the water separator uses this electricity for making hydrogen stored in a tank. When there is not enough light, hydrogen is driven to a PEM cell making electricity. 
There are a lot of ways of gaining the energy of solar radiation. Some solar plants work similarly to a conventional $\mathrm{TPP}^{14}$ where high pressure steam rotates a turbine on a common axis with an alternator, but the heat making steam is not produced by burning fossils. Largescale mirror systems can focus the light of the sun into a point where the temperature can reach hundreds of degrees. This solution hasn't enough mobility for military applications so when we're talking about solar power in military smart grids, we mean using PV cells.

As we can see the possible building blocks of micro grids are the followings:

- control unit and its sensors,

- generator(s),

- RES (in military applications that is wind and/or solar),

- storage unit (batteries or/and hydrogen cells),

- cables and switches,

- current transformers,

- power line interface(s).

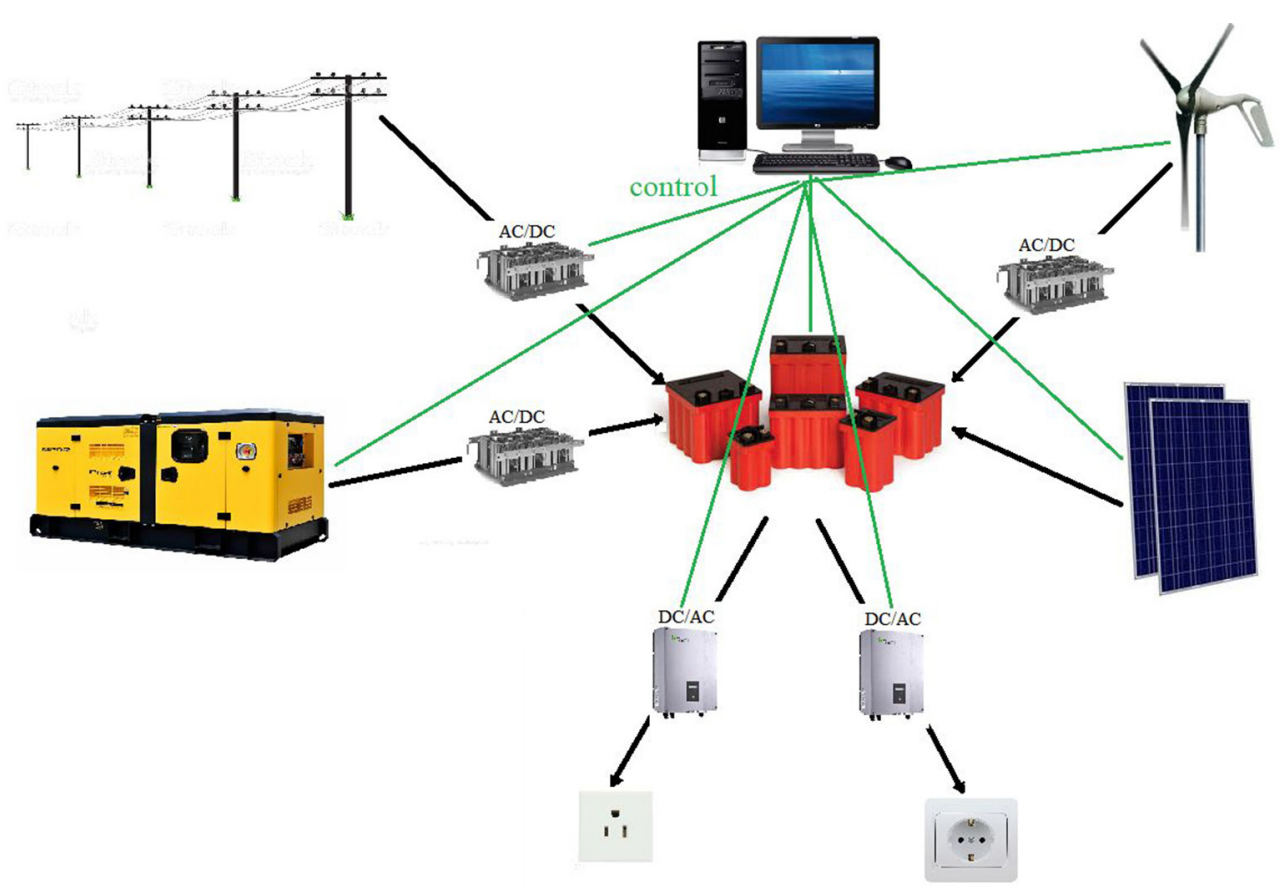

Figure 5. A possible "full-scale" smart grid structure.

[Edited by the author.]

According to the actual needs some parts may be missing. UPS ${ }^{15}$ infrastructure can be seen like a special type of micro grids. When the primary goal is to improve the reliability of the electricity supply, the micro grid is only a small capacity battery and a generator.

\footnotetext{
14 Thermal Power Plant.

15 Uninterruptable Power Supply.
} 
When the main power line is interrupted the generator starts immediately and the battery supplies the network between them. In some civil applications when the main reason of building a micro grid is economy the storage unit and the generator is commonly missing because of its price, and the micro grid essentially is a PV farm with a control unit and transformers. While the generated local power is more than the required, the surplus is fed into the network, otherwise the network recoup the local power generation. As it was mentioned, the military micro grids mostly don’t have connectors for civil power lines.

Military smart grids are made in order to get the possibility of gaining RES in field. In this application RES means almost exclusively solar power. These types of equipment have to be very mobile and must face the difficult circumstances required by military standards. Normally their structures are very similar but the current size of the components depends on the intended mode of use and the geographic position. Let's see some examples. An unmanned remotely controlled communication station can be supplied for an extremely long time without any local maintenance if it has a special smart grid. In this case the working time is limited by the locally stored fuel for generator, so the target is to minimize its run time. It means an extremely large PV surface and a massive storing capacity compared to the load of the station.

In a temporary camp the number of very expensive batteries can be reduced as the refuelling of the generator(s) is easy and more PV panels can be used. In some applications like quick reaction auxiliary power supplies, the stored energy capacity is a determinative attribute but the generator can be very small or completely abandoned.

The closer we are to the equator the angle of incoming photons is closer to $90^{\circ}$ which significantly raises the efficiency of solar panels. [13: 34] It is logical that for the same real PV power in northern places more panels are needed. There are some different PV materials in the market and they have different qualities.

Table 2. Comparison of PV types.

[The author's compilation.]

\begin{tabular}{|l|l|l|l|}
\hline Technology & Monocrystalline & Polycrystalline & Thin Film \\
\hline Material & silicon & silicon & $\begin{array}{l}\text { amorphous silicon, } \\
\text { CdTe, }{ }^{16} \text { CIGS }^{17}\end{array}$ \\
\hline Cost & moderate & low & moderate \\
\hline Efficiency & $15-24 \%$ & $16-20 \%$ & $8-12 \%$ \\
\hline Heat Resistance & moderate & high & high \\
\hline $\begin{array}{l}\text { Temperature } \\
\text { Co-Efficiency }\end{array}$ & moderate & high & minimal \\
\hline Weight & high & high & low \\
\hline Flexibility & none & none & good \\
\hline Longevity & high & moderate & poor \\
\hline
\end{tabular}

16 Cadmium Telluride.

17 Copper Indium Gallium Diselenide. 
Table 3. Comparison of battery types and fossils based on their energy density.

[The author's compilation.]

\begin{tabular}{|c|c|c|c|}
\hline \multirow{2}{*}{\multicolumn{2}{|c|}{ Material/technology }} & \multicolumn{2}{|c|}{ Maximal energy density } \\
\hline & & volume prop. & weight prop. \\
\hline \multicolumn{2}{|c|}{ alkali batteries } & $\sim 100 \mathrm{Wh} / \mathrm{l}$ & $\sim 150 \mathrm{Wh} / \mathrm{kg}$ \\
\hline \multirow{8}{*}{ 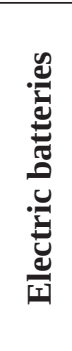 } & plumbate-acid (Pb-acid) & $\sim 40 \mathrm{Wh} / \mathrm{l}$ & $\sim 25 \mathrm{Wh} / \mathrm{kg}$ \\
\hline & nickel-cadmium (NiCd) & $\sim 150 \mathrm{Wh} / \mathrm{l}$ & $\sim 100 \mathrm{Wh} / \mathrm{kg}$ \\
\hline & nickel metal-hydride (NiMH) & $\sim 300 \mathrm{Wh} / \mathrm{l}$ & $\sim 150 \mathrm{Wh} / \mathrm{kg}$ \\
\hline & lithium-ion (Li-ion) & $\sim 650 \mathrm{Wh} / \mathrm{l}$ & $\sim 250 \mathrm{Wh} / \mathrm{kg}$ \\
\hline & lithium polymer (Li-polymer) & $\sim 700 \mathrm{Wh} / \mathrm{l}$ & $\sim 250 \mathrm{Wh} / \mathrm{kg}$ \\
\hline & lithium ferrophsophate (LiFePO4) ${ }^{3}$ & $\sim 200 \mathrm{Wh} / \mathrm{l}$ & $\sim 100 \mathrm{Wh} / \mathrm{kg}$ \\
\hline & lithium-air & $\sim 2,000 \mathrm{Wh} / \mathrm{l}$ & $\sim 1,700 \mathrm{Wh} / \mathrm{kg}$ \\
\hline & lithium-sulphur & $\sim 1,500 \mathrm{Wh} / \mathrm{l}$ & $\sim 1,000 \mathrm{Wh} / \mathrm{kg}$ \\
\hline \multicolumn{2}{|c|}{ liquid hydrogen } & $\sim 2,500 \mathrm{Wh} / \mathrm{l}$ & $\sim 39,000 \mathrm{Wh} / \mathrm{kg}$ \\
\hline \multirow{5}{*}{ 苞 } & fire wood (dry) & $\sim 700 \mathrm{Wh} / \mathrm{l}$ & $\sim 3,000 \mathrm{Wh} / \mathrm{kg}$ \\
\hline & black coal & $\sim 9,000 \mathrm{Wh} / \mathrm{l}$ & $\sim 6,500 \mathrm{Wh} / \mathrm{kg}$ \\
\hline & liquid gas & $\sim 7,000 \mathrm{Wh} / \mathrm{l}$ & $\sim 12,000 \mathrm{Wh} / \mathrm{kg}$ \\
\hline & gasoline & $\sim 9,500 \mathrm{Wh} / \mathrm{l}$ & $\sim 12,000 \mathrm{Wh} / \mathrm{kg}$ \\
\hline & diesel & $\sim 10,500 \mathrm{Wh} / \mathrm{l}$ & $\sim 13,500 \mathrm{Wh} / \mathrm{kg}$ \\
\hline \multicolumn{2}{|c|}{ uranium-235 } & $\sim 4.7 \times 10^{12} \mathrm{Wh} / \mathrm{l}$ & $\sim 2.5 \times 10^{10} \mathrm{Wh} / \mathrm{kg}$ \\
\hline
\end{tabular}

\section{The Working Method of Military Smart Grids, Advantages and Disadvantages}

The working method of an average military island smart grid is quite easy and it can be described in three simple steps:

1. RES charge the batteries and the consumers load energy from them via an inverter. ${ }^{19}$

2. The RES input doesn't cover the output and the batteries are discharging.

3. The charge of the batteries falls below a predefined level when the generator starts and recharges the batteries again.

18 The lithium-ion batteries almost dominate the smart grid technology because of their energy density but in some applications lithium ferrophosphate can be very useful because of its slightly higher temperature tolerance.

19 An electronic converter that changes DC to AC. 


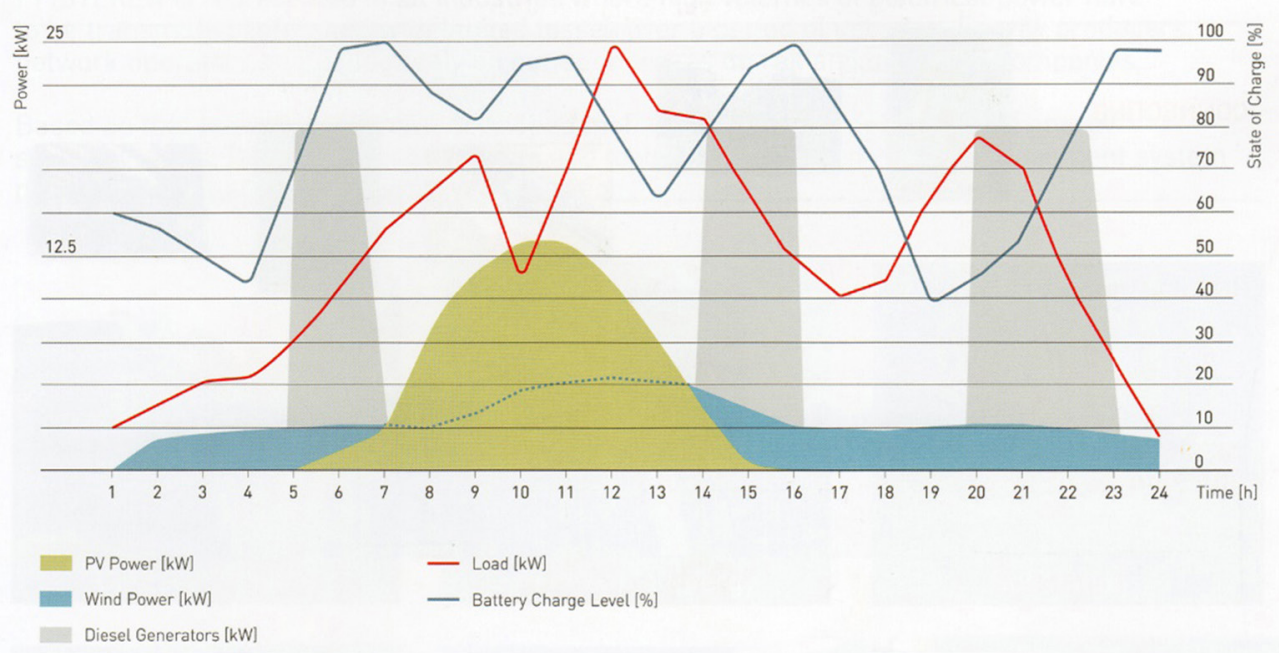

Figure 6. A recorded daily working diagram of a real smart grid. [20]

As it was mentioned several times the goal of using smart grids is to reduce the fuel consumption. But how is this accomplished? It seems very easy: when the sun shines there is no need for the generator to work. It's absolutely true but there is another reason why these structures can save fuels compared to conventional generators. And this is coming from the characteristics of diesel engines. The efficiency of diesel engines (and all other types of heat-engines) depends on the load. It's only a very narrow band close to the maximum of load when the efficiency is optimal. In other bands it can be extremely poor and even close to zero. For example, when the load is zero a conventional generator can't stop and it has to work continuously without producing electricity as it is shown very conspicuously in Figure 7.

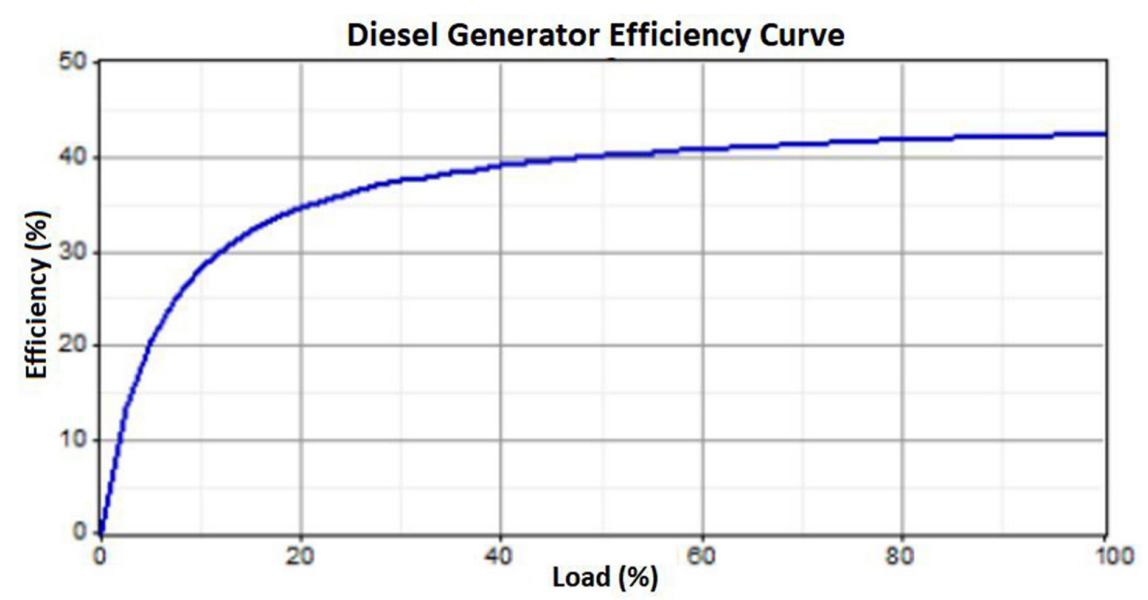

Figure 7. The efficiency of a typical diesel generator vs load. [21: 753] 
If we check again Figure 6 we can see that diesel engine started only 3 times that day and worked for 7 hours but this time it was working constantly on its optimal load. This process is so effective that it alone results up to $40 \%$ in fuel savings.[14] The efficiency of the process was revealed only during the developments of hybrid systems but since then a number of independent international practical studies has been completed with similar results. The decreasing operating time and the optimum load have other positive gain as the maintenance cost and reliability of the applied diesel engines have improved spectacularly.

Table 4. The generations of generators. [The author's compilation.]

\begin{tabular}{|l|l|l|l|l|l|}
\hline Generation & $\mathbf{0 .}$ & $\mathbf{1 .}$ & $\mathbf{2 .}$ & “2.5” & $\mathbf{3 .}$ \\
\hline Power source & muscle & gasoline & diesel & $\begin{array}{l}\text { buffered } \\
\text { diesel }\end{array}$ & hybrid \\
\hline $\begin{array}{l}\text { Typical application } \\
\text { period }\end{array}$ & $1910-1930$ & $1920-1950$ & $1940-$ now & $2015-$ now & 2010-now \\
\hline Current & DC & DC & AC & AC & AC \\
\hline Supply theory & $\begin{array}{l}\text { decentral- } \\
\text { ised }\end{array}$ & $\begin{array}{l}\text { decentral- } \\
\text { ised }\end{array}$ & centralised & $\begin{array}{l}\text { decentral- } \\
\text { ised }\end{array}$ & $\begin{array}{l}\text { decentral- } \\
\text { ised }\end{array}$ \\
\hline $\begin{array}{l}\text { Maximal thermal } \\
\text { efficiency }\end{array}$ & n/a & $18-24 \%$ & $28-36 \%$ & $36 \%$ & $36 \%$ \\
\hline Relative efficiency & n/a & 1 & 1.5 & $2.1^{20}$ & $2.1-3^{21}$ \\
\hline Relative weight ${ }^{22}$ & 5 & 1 & 1.4 & 1.8 & 2 \\
\hline $\begin{array}{l}\text { Relative efficiency vs. } \\
\text { weight }\end{array}$ & n/a & 1 & 1.07 & 1.17 & 1.5 \\
\hline Relative noise & 0.1 & 1 & 1.2 & $0.7^{23}$ & $0.3^{24}$ \\
\hline Relative visibility & 0.2 & 1 & 1.2 & 1.3 & 2 \\
\hline
\end{tabular}

The main advantage of the military smart grid systems is the decreasing fuel consumption that results longer independent mission time and improved survivability for troops. The battery power greatly improves the reliability of supply and a well-designed system requires less maintenance despite its more complex structure. The decentralized supply model assumes several smaller grids but these can be connected into a bigger one which further enhances the resilience of the supply. Of course, long power cables make some loss and as they behave like a kind of antenna the vulnerability of the system raises against electro-magnetic effects. To avoid those effects further items like high voltage transformers and surge protectors are required.

Unfortunately, RES has an undesirable effect on the shielding of the camps. PV panels need direct solar radiation so those can't be camouflaged and the glitter of the large panels

\footnotetext{
20 The efficiency of a conventional diesel engine $+40 \%$ surplus.

21 The efficiency of a buffered diesel +estimated solar power under normal continental conditions.

22 The output power compared to the weight of the device.

23 Of course, the noise of the diesel engine is always the same, but in buffered or hybrid systems it works significantly less.

24 Of course, the noise of the diesel engine is always the same, but in buffered or hybrid systems it works significantly less.

25 The output power compared to the size of the device.
} 
can reveal the location of the camp from very far. From this point of view, the application of wind power is even more risky. For more efficient power production, a larger pole is needed but that extremely raises the visibility. These kinds of equipment are very noisy and the large moving rotors have surprisingly big radar cross-section.

The fuel consumption of the grid can be reduced up to $40-80 \%$ depending on the actual implementation [15] but it can't counteract the fact that these devices are extremely expensive. Primarily because of the cost of batteries - the investment cost of such device is three-five times more than the cost of a conventional generator. Because of the more complicated structure these are larger and heavier than normal diesel generators and that means more logistic demand. Due to their more numerous components their full deploy time is much longer and if the batteries are charged then hybrid systems can be loaded immediately and there is no need for warm up time and it is not necessary to wait for the full installation.

\section{The Main Types of Existing Systems}

As it was noted before, military smart grid technology is totally based on the civil grids so the most important developers are civilian energy companies. Around the turn of the Millennium they recognized that the demands of armed forces are similar to some conventional civil applications. In Europe NATO and EDA ${ }^{26}$ recognised the military significance of this technology and strongly support its spread.

Now the main scenes of the appearance of these devices are "Capable Logistician" international military logistics exercises. These events are organized by MLCC ${ }^{27}$ and supported by NATO ESCD. ${ }^{28}$ The last exercise was held in Várpalota, Hungary where more than 2,000 soldiers of 27 nations were practicing co-operation during 2 weeks. [12: 3] It was the first time in Europe when military smart grids were not only exhibited but were integrated into the power supply system of the exercise. So far, no country has ever deployed smart grid system but some of them plan to do so. Besides the developer companies two major military projects are being conducted. NATO ENSEC $\mathrm{COE}^{29}$ has a great experimental equipment in Vilnius built by the German company, Pfisterer and EDA deployed another one in Mali built by the British BAE Systems. [16]

In fact, the first military smart grids are already existing products with ruggedized design. These types have high performance according to industrial needs. Their military versions are normally built in a standard container in order to be easily transferable. These are designed for supplying temporary camps, independently deployed medium size military units for longer time so their full installation takes more time, up to some hours.

The design principles of these kinds of equipment are as follows:

- RES can be wind or solar power. The applied devices are usually fixedly installed on the roof of containers or tents;

26 European Defence Agency is an independent European organization in Brussels, Belgium. Its main purpose is to provide place to co-operation of the European military developments.

27 Multinational Logistic Coordination Centre is an independent international organization in Praha, Czech Republic. Its main purpose is to develop military logistics and organize military logistic events.

28 Emergency Security Challenges Division in the Headquarters of NATO in Brussels, Belgium.

29 Energy Security Centre of Excellence is a NATO organization in Vilnius, Lithuania. 
- the power management system prefers RES but it also has a powerful diesel generator in order to secure and stable energy supply constantly;

- these are modular. Each container can be assembled to the specific needs of the user. These are easily scalable for output from $25 \mathrm{kw}$ to $1 \mathrm{mw}$;

- consumers can be prioritised;

- these operate remotely without local supervision;

- generators and PV panels can be a third-party product or an existing item;

- containers contain only the management system and the batteries. In order to use the highest energy density Li-ion batteries the containers are air-conditioned that eliminates the temperature dependency of capacity of these kinds of batteries.

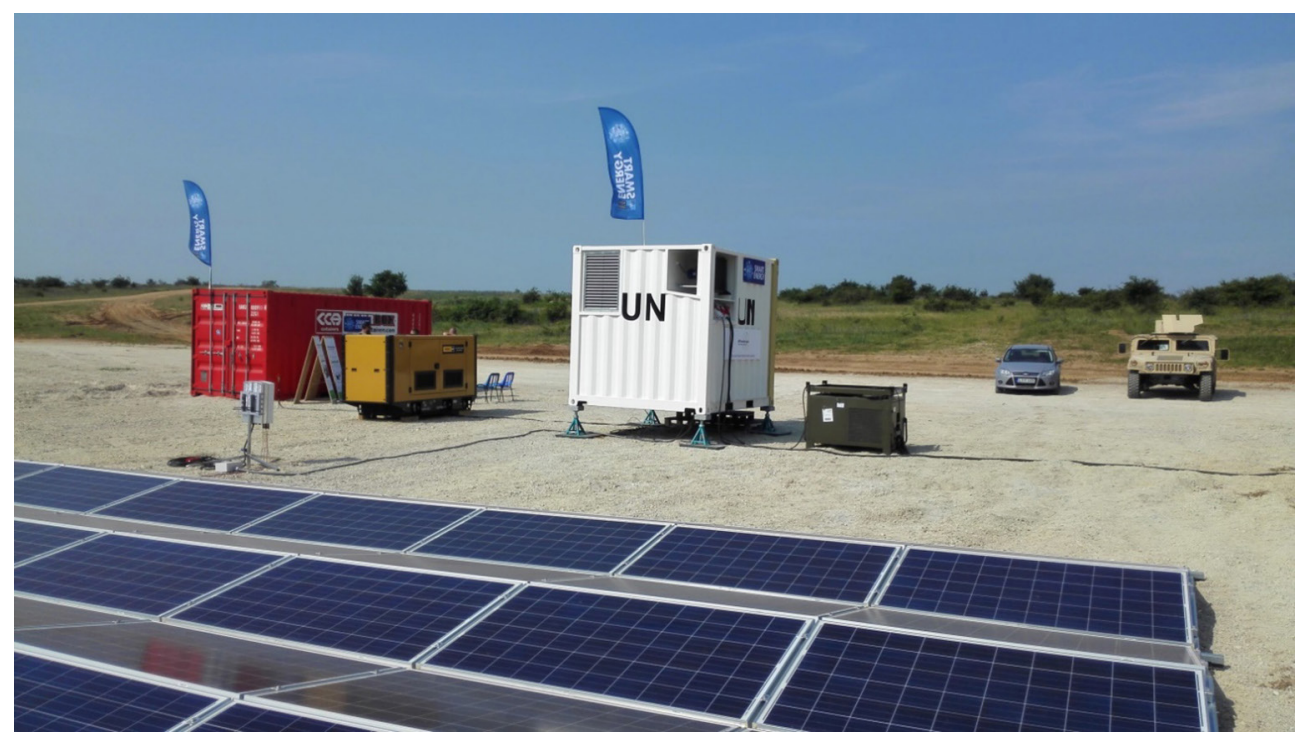

Figure 8. The equipment of Dutch ESTechnologies operating on CL15 exercise in Várpalota supplied a battalion-size camp. ${ }^{30}$ [The author's photo.]

Later on, another type of military smart grid emerged driven by military needs. These small-size mobile devices have variable possible applications. These are usable for supplying quick move and installing smaller military units like a platoon or company. These are also usable for temporary strengthening a micro grid or temporary maintaining a facility during a blackout. Their typical application is the solar-trailer (a towed chassis with quickly expellable PV panels) but there are also some other construction principles.

The design principles of these kinds of equipment are as follows:

- these are very mobile, lightweight units. Their full installation time is only some minutes;

- RES can be only solar. Panels are quickly deployable and redeployable using some

30 The total PV surface is $120 \mathrm{~m}^{2}$ with $18 \mathrm{~kW}$ nominal power. The white container contains the management system and $140 \mathrm{kWh}$ total capacity battery group. PV panels arrived in the red container. The orange box in the middle is the standard Caterpillar diesel generator. The green box is the power interface of the tent camp. 
mechanical assistance;

- only PV sets and power transformers are compulsory. Diesel generators or even batteries may be absent in some cases;

- the most applicable battery type is Lithium-ferrophosphate. As air-conditioned housing is not possible, so the preferred feature of this type is that its capacity is less dependent on the temperature although the available energy density is lower than Li-ion;

- these are only partially modular. Only the size of the batteries or the types of the inverters can be changed.

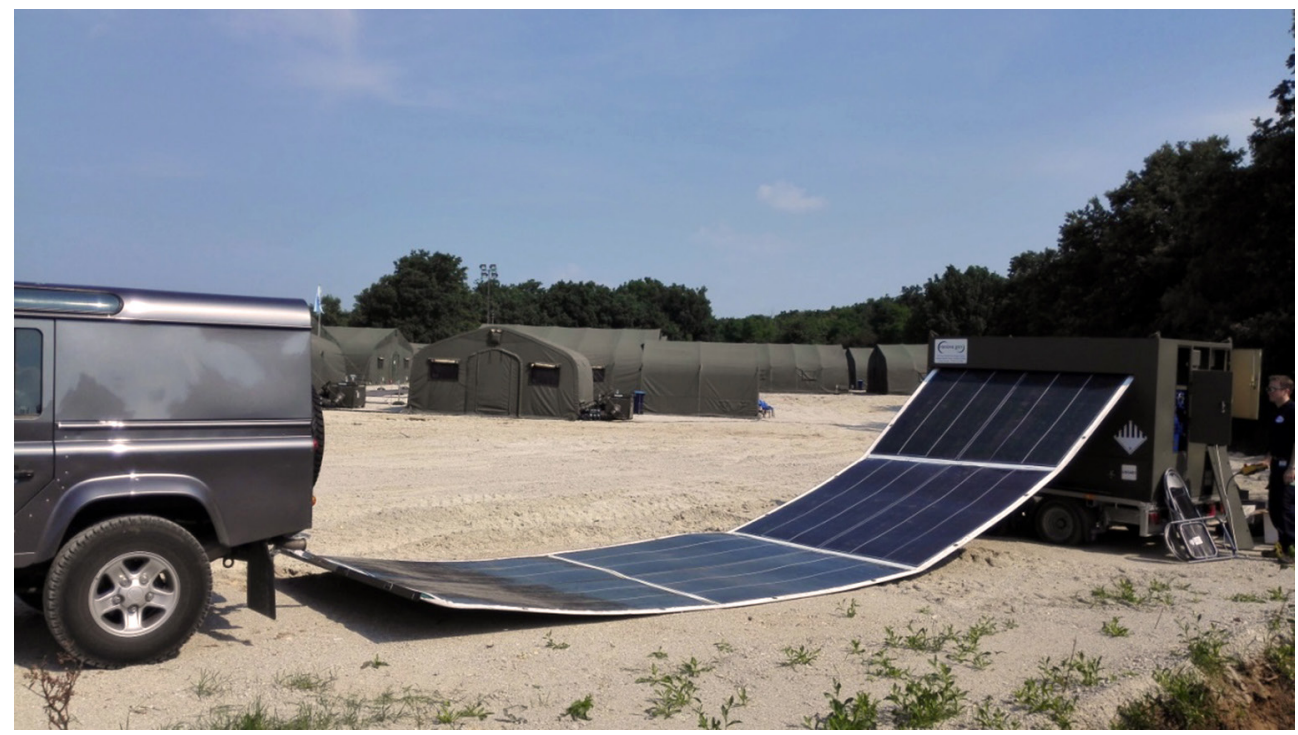

Figure 9. The theory of the British Renovagen is very special and compact. The trailer contains the retractable solar-carpet and the inverters. The tractor Land Rover helps the quick deploy.

[The author's photo.]

\section{Summary}

Overall, we can state that military smart grid is a very innovative and modern technology. Using these systems causes a really substantial reduction in fuel consumption unlike the residual heat-recovery or additives and emulsions in the diesel engine. Despite all that, their explosive propagation is not expected because of the price of the essential batteries. But as the battery costs fall, this kind of equipment will become more and more common in the armed forces and other law enforcement agencies.

According to some calculations the great investment is already recoverable during peace-keeping or peace-enforcing military operations as within a few years-if we calculate with extremely high fuel prices (3 EUR/l) — the transportation and storage costs will be very high. However, the spread of container type smart grids is more likely where the main aspect is to reduce vulnerable fuel supply caravans and increase survivability of our troops. 
In some cases, it is worth considering the settlement of a bigger smart grid in a permanent military facility where there are no power lines within hundreds of kilometres. In Hungary all the facilities owned by the army are connected to the domestic electrical network therefore the application of larger systems in Hungary is currently not planned. At this moment the Hungarian troops performing service abroad are supplied by allied logistic units but if we deployed a bigger Hungarian contingent independently it would be worth taking into account the acquisition of a smart grid.

The situation is much simpler for the mobile military smart grids. For these devices, the lower price can even be further reduced with the proper scaling and omitting the unnecessary parts. Due to their high degree of mobility, they can be an ideal addition to the telecommunication stations, command and control centres and field medical facilities. These kinds of equipment are particularly suitable for ensuring the power supply of unsupervised military bases.

\section{References}

[1] BP Statistical Review of World Energy. London: British Petrol, 2017.

[2] PARMAR, J.: Total Losses in Power Distribution and Transmission Lines. EEP - Electrical Engineering Portal, 19.08.2013 http://electrical-engineering-portal.com/ total-losses-in-power-distribution-and-transmission-lines-1 (Downloaded: 19.11.2017)

[3] BRYCE, R.: Gas Pains. The Atlantic, 05.2005. www.theatlantic.com/magazine/ archive/2005/05/gas-pains/303897/. (Downloaded: 30.08.2017)

[4] VÁNYA L.: Irányított energiájú fegyverek. Budapest: Nemzeti Közszolgálati Egyetem, 2013.

[5] VÉGVÁRI ZS.: A katonai aggregátorfejlesztés- és gyártás történeti áttekintése, különös tekintettel a villamos forgógépek magyarországi gyártására 1927-1954 között. Katonai Logisztika, 24 különszám (2016), 564-579.

[6] HERMAN, S. L.: Electrical Transformers and Rotating Machines. New York: Delmar, Cengage Learning, 2012.

[7] CHAPMAN, S. J.: Electric Machinery Fundamentals. New York: McGraw-Hill, 2012.

[8] ROOS, D.: Biofuels vs. Fossil Fuels. 20.08.2012. http://auto.howstuffworks.com/fuelefficiency/biofuels/biofuel-fossil-fuel.htm. (Downloaded: 02.09.2017)

[9] GERŐCS I.: The military and the renewables. Hadtudományi Szemle, 5 1-2 (2012), 300-314.

[10] GUPTA, H., ROY, S.: Geothermal Energy: An Alternative Resource for the $21^{\text {th }}$ Century. Amsterdam: Elsevier Academic Press, 2007.

[11] VÉGVÁRI ZS.: A megújuló villamos-energiaforrások felhasználásnak lehetőségei harctéri körülmények között. Hadmérnök, 111 (2016), 41-56.

[12] VÉGVÁRI ZS.: A Smart Energy koncepció és eszközei a CL15 logisztikai gyakorlaton 1. rész. Haditechnika, 496 (2015), 30-34.

[13] MERTENS, K.: Photovoltaics: Fundamentals, Technology and Practice. Chicester: John Wiley \& Sons Inc, 2014.

[14] ZOTOS, A.: Renewable Energy Sourced Camp Smart Microgrid. Brussels: EDA Energy and Environment WG, 2017. 
M. CSUKAI, P. RUZSONYI: Juvenile Boot Camps in the Shadow of Tragedies

[15] VÉGVÁRI ZS.: A Smart Energy koncepció és eszközei a CL15 logisztikai gyakorlaton 2. rész. Haditechnika, 502 (2016), 44-48.

[16] WOODMAN, J.: Smart Energy Camp Final Report. Farnborough: BAE Systems, 2016.

[17] Wehrmacht. Awards.com. www.wehrmacht-awards.com/forums/showthread. php?p=7823476 (Downloaded: 01.03.2018)

[18] Pinterest. www.pinterest.co.uk/pin/391813236323258580/?lp=true (Downloaded: 01.03.2018)

[19] 100528-N-3136P-207. www.navy.mil/view_image.asp?id=86206 (Downloaded: 01.03.2018)

[20] Flyer broshure of Pfisterer's CrossPower system.

[21] NOUR, M., ROHANI, G.: Prospect of Stand-Alone PV-Diesel Hybrid Power System for Rural Electrification in UAE. International Journal of Renewable Energy Research, 43 (2014), 749-758. 